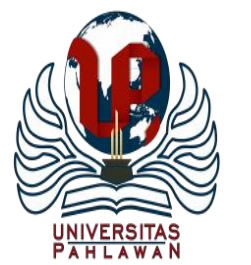

Edukatif : Jurnal Ilmu Pendidikan Volume 3 Nomor 3 Tahun 2021 Halm 972 - 979

EDUKATIF: JURNAL ILMU PENDIDIKAN

Research \& Learning in Education

https://edukatif.org/index.php/edukatif/index

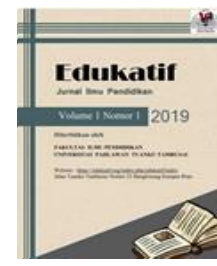

\title{
Peningkatan Kompetensi Menyusun Rencana Pembelajaran Melalui Model Project Based Learning pada Mahasiswa PGSD
}

\author{
Manggu Ngguna Raji ${ }^{1 凶}$, Felix Welu ${ }^{2}$ \\ Prodi PGSD universitas Flores, Indonesia ${ }^{1,2}$ \\ E-mail : mangguraji9573@gmail.com ${ }^{1}$, felix.welu@ gmail.com ${ }^{2}$
}

\begin{abstract}
Abstrak
Penelitian ini dilatarbelakangi oleh permasalahan masih kurangnya kemampuan mahasiswa PGSD Uniflor dalam menyusun rencana pelaksanaan pembelajaran IPS SD. Penelitian ini bertujuan untuk meningkatkan kompetensi mahasiswa PGSD Universitas Flores untuk menyusun perencanaan pembelajaran melalui model project based learning. Jenis penelitian ini adalah penelitian tindakan kelas dengan tahapan perencaaan, tindakan, observasi dan refleksi. Subjek penelitian adalah mahasiswa PGSD Univeristas Flores yang mengikuti perkuliahan desain pembelajaran IPS dengan jumlah sebanyak 34 orang. Data diambil dengan teknik dokumentasi, observasi dan catatan lapangan. Data dianalisis dengan langkah pengumpulan data, penyajian data dan verifikasi. Hasil penelitian menunjukkan bahwa setelah diterapkan model project based learning kompetensi mahasiswa dalam menyusun perencanaan pembelajaran IPS SD meningkat dari siklus I sebesar 68\% menjadi $85 \%$ pada siklus II. Dengan demikian, model project based learning dapat meningkatkan kemampuan mahasiswa PGSD Universitas Flores dalam menyusun perencanaan pembelajaran IPS SD.
\end{abstract}

Kata Kunci: Project based Learning, Perencanaan Pembelajaran.

\begin{abstract}
This research was motivated by the problem of the lack of ability of PGSD Uniflor students in compiling plans for the implementation of SD social studies learning. This study aims to improve the competence of PGSD students at the University of Flores to prepare lesson plans through a project-based learning model. This type of research is a classroom action research with the stages of planning, action, observation and reflection. The research subjects were PGSD students of the University of Flores who attended the social studies learning design lectures with a total of 34 people. The data were collected using documentation techniques, observation and field notes. The data were analyzed using the steps of data collection, data presentation and verification. The results showed that after the application of the project based learning model, the competence of students in preparing social studies learning planning for SD increased from $68 \%$ to $85 \%$ in cycle II. Thus, the projectbased learning model can improve the ability of PGSD students at the University of Flores in preparing lesson plan of social study in elementary school.
\end{abstract}

Keywords: Project based Learning, Lesson Plan.

Copyright (c) 2021 Manggu Ngguna Raji, Felix Welu

$\triangle$ Corresponding author

Email : mangguraji9573@gmail.com

DOI : https://doi.org/10.31004/edukatif.v3i3.488

ISSN 2656-8063 (Media Cetak)

ISSN 2656-8071 (Media Online)

Edukatif : Jurnal Ilmu Pendidikan Vol 3 No 3 Tahun 2021

p-ISSN 2656-8063 e-ISSN 2656-8071 


\section{PENDAHULUAN}

Rencana Pelaksanaan Pembelajaran (RPP) merupakan salah satu kompetensi penting yang harus dikuasai oleh seorang guru. Trianto mengungkapkan RPP adalah langkah-langkah yang akan dilakukan guru dalam kegiatan pembelajaran yang disusun dalam skenario kegiatan (Setiana, 2018). Kualitas sebuah RPP dikatakan baik apabila memuat secara detail semua hal yang akan dilakukan di dalam kelas dan tujuan yang diharapkan untuk dilakukan siswa dalam satu satuan waktu pembelajaran. Mengingat pentingnya kompetensi ini bagi seorang guru, maka setiap calon guru perlu dibekali dengan pengetahuan tersebut. upaya itu dilakukan oleh program studi pendidikan guru sekolah dasar Universitas Flores melalui berbagai perkuliahan desain pembelajaran, salah satunya adalah mata kuliah desain pembelajaran IPS SD.

Mata kuliah desain pembelajaran IPS SD merupakan mata kuliah yang bertujuan untuk memfasilitasi mahasiswa PGSD Universitas Flores untuk dapat mengembangkan perencanaan pembelajaran IPS di sekolah dasar berdasarkan kurikulum yang berlaku serta menginternalisasi visi misi kampus dan program studi yakni sebagai kampus mediator budaya. Dalam menyelenggarakan perkuliahan tersebut, mahasiswa diharapkan dapat membuat RPP IPS SD yang bermuatan nilai dan konsep budaya lokal serta mampu melaksanakan simulasi pembelajaran (peer teaching) sesuai RPP yang telah dibuat. Namun harapan yang diinginkan belum sepenuhnya tercapai dengan baik. Fakta yang ditemukan dalam kelas-kelas perkuliahan desain pembelajaran IPS menunjukkan masih banyak mahasiswa yang belum kreatif menghubungkan konten lokal yang ada disekitarnya ke dalam desain perencanaan pembelajarannya. Pada umumnya RPP yang dibuat oleh mahasiswa masih mengacu pada buku guru dan hasil unduhan dari internet. Hal ini tentu menghadapkan pemangku mata kuliah ke dalam sebuah pertanyaan refleksi apakah startegi perkuliahan yang diterapkan sudah tepat.

Hasil refleksi dan diskusi teman sejawat antara pemangku kuliah, menjawab permasalahan tersebut melalui sebuah solusi strategi pembelajaran yang diharapkan dapat membuat mahasiswa menjadi lebih kreatif. Strategi tersebut adalah dengan menerapkan model Project based learning (PBL). PBL adalah suatu model yang dapat mengorganisir proyek-proyek dalam pembelajaran (Rais, 2007; Surya et al., 2018). Project basedlearning memberi peluang pada sistem pembelajaran yang berpusat pada mahasiswa, lebih kolaboratif, mahasiswa terlibat secara aktif menyelesaikan proyek-proyek secara mandiri dan bekerja sama dalam tim dan mengintegrasikan masalah-masalah yang nyata dan praktis (Fitri et al., 2018; Irianti, 2017; Mulyadi, 2016; Rahmazatullaili et al., 2017). Hal tersebut sesuai dengan konsep belajar bermakna yang disampaikan Aussubel bahwa setiap pembelajar mengkonstruksi apa yang telah ia pelajari dan mengasosiasikan pengalaman, fenomena, dan fakta-fakta baru ke dalam struktur pengetahuan mereka (Rahmah, 2018).

Melalui proses kontruksi pengetahuan dalam PjBL, mahasiswa dapat lebih aktif dan kreatif menemukan dan mengembangkan perencanaan pembelajaran sesuai harapan dalam perkuliahan desain pembelajaran IPS SD. Hal senada disampaikan bahwa Project based learning merupakan pembelajaran inovatif yang berpusat pada peserta didik (student centered) dan menempatkan guru sebagai motivator dan fasilitator, di mana peserta didik diberi peluang bekerja secara otonom mengkonstruksi belajarnya (Suranti et al., 2017). Pembelajaran berbasis proyek (PjBL) yang terdiri proyek yang mengintegrasikan ilmu pengetahuan, teknologi, masyarakat, sejarah, matematika, politik dan kesempatan diskusi produktif untuk siswa, mendorong penyelidikan siswa diarahkan masalah dunia nyata, memberikan mereka semangat belajar dan pengajaran menjadi efektif (Turgut dalam Munawaroh et al., 2012).

Meninjau dari kebermanfaatan model PjBL yang dapat mengembangkan kemampuan kritis mahasiswa dalam memecahkan masalah (Istiqomah \& Indarini, 2021), maka perlu diterapkan hal serupa yang bertujuan untuk dapat meningkatkan kompetensi mahasiswa PGSD Uniflor dalam menyusun perangkat pembelajaran. Model PjBL telah terbukti dapat meningkatkan kemampuan mahasiswa dalam sejumlah proses perkuliahan desain pembelajaran. Hal ini dapat ditinjau dalam penelitian yang sebelumnya dilakukan oleh (Nurjaman et al., 2018) pada sejumlah mahasiswa pendidikan matematika. Penelitian tersebut membuktikan bahwa model 
974 Peningkatan Kompetensi Menyusun Rencana Pembelajaran Melalui Model Project Based Learning pada Mahasiswa PGSD - Manggu Ngguna Raji, Felix Welu

DOI : https://doi.org/10.31004/edukatif.v3i3.488

PjBL dapat meningkatkan kemampuan mahasiswa dalam menyusun RPP. Dengan demikian dilakukanlah penelitian ini untuk meningkatkan kompetensi menyusun RPP IPS SD pada mahasiswa PGSD Universitas Flores melalui model PjBL.

\section{METODE}

Penelitian ini merupakan penelitian tindakan kelas (PTK) dengan dengan pendekatan deskriptif kualitatif. Subjek dalam penelitian ini adalah mahasiswa prodi PGSD Universitas Flores yang mengikuti perkuliahan desain pembelajaran IPS SD. Jumlah subjek penelitian sebanyak 34 orang. Data dikumpulkan dengan teknik dokumentasi, observasi dan catatan lapangan. Dokumentasi digunakan untuk mengumpulkan data RPP mahasiswa, observasi digunakan untuk mengambil data pelaksanaan perkuliahan dengan model PjBL serta catatan lapangan digunakan untuk melengkapi data-data pendukung penelitian ini seperti kejadian atau peristiwa tidak terduga dalam proses penelitian.

Instrumen penelitian ini terdiri atas lembar penilaian RPP, pedoman observasi keterlaksanaan pembelajaran dengan model PjBL serta lembar catatan lapangan. Data yang dikumpulkan kemudian dianalisa menggunakan teknik analisis interaktif Miles Huberman yakni pengumpulan data, penyajian data dan verifikasi atau kesimpulan. Penelitian dilaksanakan dengan prosedur PTK yang bersifat siklik dengan tahapan perencanaan, tindakan, observasi dan refleksi. Adapun indikator kinerja setiap siklus adalah apabila RPP yang dihasilkan telah mencapai kriteria baik atau sangat baik maka tindakan akan dihentikan.

\section{HASIL DAN PEMBAHASAN}

Penelitian ini bertujuan untuk meningkatkan kemampuan mahasiswa PGSD Universitas Flores dalam merancang RPP. Penelitian ini dilaksanakan dalam dua siklus. Setiap siklus terdiri atas tahapan perencanaan, tindakan, observasi dan refleksi. Hasil penelitian setiap siklus dijelaskan dalam poin-poin berikut.

Siklus I. Tahapan perencanaan dalam siklus I dilakukan peneliti dengan mempersiapkan kelengkapankelengkapan kegiatan perkuliahan seperti rencana perkuliahan semester (RPS) dan materi perkuliahan dalam bentuk power point dan bahan ajar.Tahap tindakan merupakan tahap penerapan model PjBL. Tahap ini dilakukan dalam tiga kali pertemuan. Pertemuan pertama diawali dengan kegiatan orientasi masalah. Pada tahapan ini dosen menyuguhkan terlebih dahulu potensi-potensi budaya lokal setempat seperti ritual adat, rumah adat, pakaian daerah, cerita rakyat, tarian serta lagu daerah. Dosen memberikan satu contoh mengenai relevansi budaya lokal dengan pembelajaran IPS di SD. Dalam pertemuan tersebut, dosen memberikan contoh bentuk kebudayaan lokal seperti cerita rakyat mengenai pahlawan-pahlawan daerah setempat. Melalui tanya jawab, dosen mengarahkan mahasiswa untuk menganalisis relevansi konten lokal tersebut dengan kompetensi dasar mata pelajaran IPS SD serta bagaimana mengimplementasikan konten tersebut ke dalam perencanaan pembelajaran.

Pada pertemuan kedua, mahasiswa dielaborasi melalui kelompok belajar. Tiap kelompok diberi permasalahan dengan tema konten lokal yang berbeda-beda, antara lain kelompok tarian daerah, kelompok rumah adat, kelompok pakaian adat, kelompok ritual adat dan kelompok lagu daerah. Kelompok-kelompok tersebut kemudian diberi tugas atau proyek untuk mengembangkan RPP sesuai tema yang diberikan berdasarkan langkah-langkah yang telah dipaparkan dalam pertemuan 1. Setiap tim kemudian diberi waktu satu minggu untuk menyelesaikan proyek tersebut.

Pertemuan ketiga merupakan tahap presentasi dan penilaian terhadap produk RPP yang dikembangkan. Terdapat 5 produk RPP yang dipresentasikan masing-masing tim. Bagian-bagian RPP telah ditulis secara lengkap dari identitas sampai pada tahap penilaian. Semua RPP juga telah mencantumkan langkah-langkah 
pembelajaran yang terdiri dari kegiatan pendahuluan, kegiatan pencapaian kompetensi/inti, dan kegiatan penutup, namun hampir sebagian besar RPP juga tidak mencantumkan secara lengkap instrumen penilaian, soal tes maupun lembar kerja siswa. Dua RPP juga masih ditemukan kesalahan dalam penulisan rumusan tujuan pembelajaran. Sehingga perolehan nilai produk mahasiswa belum maksimal. RPP tersebut dinilai dengan menggunakan skala Likert 1-4. Dengan total skor maksimal 40. Skor yang diperoleh tiap RPP kemudian dikonversikan ke dalam persentase dan ditentukan kriteria RPP sesuai Tabel 1. Hasil penilaian dapat dilihat pada Tabel 2.

Tabel 1 Kategori Deskriptif Persentase

\begin{tabular}{|l|l|}
\hline \multicolumn{1}{|c|}{ Interval Persentase } & Kategori \\
\hline $82-100$ & Sangat Baik \\
\hline $63-81$ & Baik \\
\hline $44-62$ & Cukup \\
\hline $22-43$ & Kurang \\
\hline$X<25$ & Sangat Kurang \\
\hline
\end{tabular}

(Sumber: Instrumen Penilaian RPP mata kulaih desain pembelajaran IPS SD)

Tabel 2 Hasil Penilaian RPP

\begin{tabular}{|c|c|c|c|c|c|c|}
\hline \multirow[t]{2}{*}{ No } & \multirow[t]{2}{*}{ Indikator } & \multicolumn{5}{|c|}{ Skor } \\
\hline & & RPP 1 & RPP 2 & RPP 3 & $\begin{array}{l}\text { RPP } \\
4\end{array}$ & RPP 5 \\
\hline 1 & Identitas RPP & 4 & 4 & 4 & 4 & 4 \\
\hline 2 & Kompetensi Inti & 4 & 4 & 4 & 4 & 4 \\
\hline 3 & Kompetensi Dasar & 4 & 4 & 4 & 4 & 4 \\
\hline 4 & Rumusan Indikator & 3 & 3 & 3 & 1 & 1 \\
\hline 5 & Rumusan Tujuan Pembelajaran & 3 & 3 & 3 & 1 & 1 \\
\hline 6 & Materi & 3 & 3 & 3 & 3 & 3 \\
\hline 7 & Strategi Pembelajaran & 3 & 2 & 3 & 1 & 1 \\
\hline 8 & Langkah Kegiatan Pembelajaran & 3 & 2 & 3 & 2 & 2 \\
\hline 9 & Media dan Sumber belajar & 2 & 2 & 3 & 2 & 2 \\
\hline 10 & Penilaian & 2 & 1 & 1 & 1 & 1 \\
\hline & Total Skor & 31 & 28 & 31 & 23 & 23 \\
\hline & Persentase $(\%)$ & 78 & 70 & 78 & 58 & 58 \\
\hline & Persentase rata-rata & & & $68 \%$ & & \\
\hline
\end{tabular}

(sumber: data diolah)

Berdasarkan Tabel 2 diperoleh data penilaian RPP 1 dan RPP 3 mendapat nilai sebesar 78\%. Apabila ditinjau dari Tabel 1, nilai tersebut berada dalam kategori Baik. Sedangkan RPP 2 mendapat nilai sebesar 70 atau dalam kategori Baik. Adapun RPP 4 dan RPP 5 mendapat nilai sebesar 58. Nilai tersebut berada dalam kategori cukup.Refleksi. Sesuai hasil yang diperoleh pada siklus 1 maka dapat direfleksikan hal-hal sebagai berikut: 1)Terdapat tiga RPP yang sudah mendapat katgeori baik,dua RPP lainnya masih dalam kategori cukup. Temuan ini belum memenuhi target penelitian yang diinginkan sehingga perlu adanya tindakan siklus 2. 2) Sebagian besar tim belum melengkapi lampiran-lampiran RPP seperti LKS, soal dan instrumen penilaian.

Siklus II dilaksanakan dengan memerhatikan kekurangan-kekurangan dari tindakan siklus I. Tahapan pelaksanaan siklus II dilakukan dengan perencanaan, tindakan, observasi dan refleksi. Adapun deskripsi tiap langkah dijelaskan dalam poin-poin berikut. Perencanaan tindakan dilakukan dengan mempersiapkan kembali RPS, media dan bahan ajar. Pada siklus I kekurangan yang ditemukan karena mahasiswa belum menuliskan RPP secara lengkap. Sehingga peneliti melengkapi bahan ajar dengan contoh RPP lengkap agar bisa dijadikan rujukan bagi mahasiswa. 
Tahap ini kembali dilakukan dengan orientasi masalah sambil bertanya jawab dan mendiskusikan kekurangan-kekurangan dalam RPP yang telah dikembangkan. Kemudian mahasiswa kembali dielaborasi dalam tim dan mengerjakan serta melengkapi tugas atau proyek RPP. Setiap tim juga dibagikan contoh RPP lengkap yang dianjurkan sebagai bahan rujukan dalam mengembangkan RPP. Proses ini juga membutuhkan tiga kali pertemuan seperti halnya siklus I yang diakhiri dengan fase presentasi dan penilaian produk RPP. Berdasarkan hasil observasi dan dokumentasi ditemkan bahwa RPP yang dikembangkan seluruhnya telah mencantumkan lampiran-lampiran seperti LKS, soal dan instrumen penilaian. Adapun hasil penilaian RPP di siklus 2 disajikan dalam Tabel 3.

Tabel 3 Hasil Penilaian RPP

\begin{tabular}{|c|c|c|c|c|c|c|}
\hline \multirow[t]{2}{*}{ No } & \multirow[t]{2}{*}{ Indikator } & \multicolumn{5}{|c|}{ Skor } \\
\hline & & RPP 1 & RPP 2 & RPP 3 & RPP 4 & RPP 5 \\
\hline 1 & Identitas RPP & 4 & 4 & 4 & 4 & 4 \\
\hline 2 & Kompetensi Inti & 4 & 4 & 4 & 4 & 4 \\
\hline 3 & Kompetensi Dasar & 4 & 4 & 4 & 4 & 4 \\
\hline 4 & Rumusan Indikator & 3 & 3 & 3 & 3 & 3 \\
\hline 5 & Rumusan Tujuan Pembelajaran & 4 & 4 & 3 & 3 & 3 \\
\hline 6 & Materi & 4 & 4 & 3 & 3 & 3 \\
\hline 7 & Strategi Pembelajaran & 3 & 3 & 3 & 3 & 3 \\
\hline 8 & Langkah Kegiatan Pembelajaran & 3 & 3 & 3 & 3 & 3 \\
\hline 9 & Media dan Sumber belajar & 3 & 3 & 3 & 3 & 3 \\
\hline 10 & Penilaian & 3 & 3 & 3 & 3 & 3 \\
\hline & Total Skor & 35 & 35 & 33 & 33 & 33 \\
\hline & Persentase $(\%)$ & 88 & 88 & 83 & 83 & 83 \\
\hline
\end{tabular}

( Sumber: data diolah)

Tabel 3 menunjukkan perolehan nilai dalam siklus I. RPP 1 dan RPP 2 masing-masing mendapat nilai $88 \%$ atau dalam kategori sangat baik. Sedangkan tiga RPP lainnya mendapat persentase sebesar 83 dengan kategori sangat baik. Sesuai nilai yang diperoleh dalam Tabel 3, maka seluruh RPP telah mencapai kategori atau indikator kinerja yang ditetapkan dalam penelitian ini. Apabila dibandingkan dengan siklus I terdapat peningkatan kompetensi penyusunan RPP yang dikembangkan mahasiswa. Dimana di siklus I terdapat 3 RPP dalam kategori baik dan 2 RPP dalam kategori cukup. Sedangkan di siklus II seluruh RPP meningkat ke dalam kategori sangat baik.

Keberhasilan suatu proses pembelajaran sangat ditentukan oleh perencanaan yang dibuat guru. Menurut Madjid (Nadzir, 2013), perencanaan pembelajaran mencakup proses pemyusunan materi pembelajaran, media, strategi pembelajaran, dan penilaian untuk mencapai suatu tujuan pembelajaran yang telah ditetapkan. Definisi tersebut mengindikasikan bahwa RPP memiliki komponen-komponen yang disusun dengan benar dan sistematis. Dalam konteks penelitian ini, diperoleh data penyusunan RPP berbasis konten lokal setelah diterapkan model PjBL dalam dua siklus. Komponen-komponen RPP tersebut meliputi identitas RPP, kompetensi inti dan kompetensi dasar, indikator dan tujuan pembelajaran, materi ajar, strategi pembelajaran, langkah kegiatan belajar, media dan sumber belajar serta penilaian.

Identitas RPP merupakan bagian pertama dari sebuah komponen RPP. Berdasarkan hasil penelitian, bagian ini ditulis dengan sangat baik dan lengkap oleh mahasiswa. Begitupun dalam komponen kompetensi inti (KI) dan kompetensi dasar (KD) ditulis dengan benar dan terurut. Mahasiswa mampu menghubungkan tema dan subtema berbasis konten lokal terhadap KI dan KD IPS SD dengan sangat baik. Untuk dapat menentukan tema tersebut, mahasiswa harus menganalisis dan memilih KI dan KD yang sesuai dengan konten lokal, dimana konten lokal tersebut adalah permasalahan yang diajukan dosen untuk dipecahkan mahasiswa 
melalui penerapan model PjBL. Hal ini membuktikan bahwa model PjBL berhasil meningkatkan kemampuan mahasiswa dalam memecahkan masalah yang diberikan. Hal senada juga dibuktikan melalui penelitian (Prabawa, 2017) pada sejumlah siswa di SMPN 1 Wates dimana model PjBL dapat meningkatkan kemampuan siswa dalam memecahkan masalah matematika yang diberikan guru.

Menentukan identitas, KI dan KD merupakan prosedur awal dalam RPP. Selanjutnya, RPP harus dapat dikembangkan ke dalam komponen-kompenen yang lebih detail. Komponen tersebut adalah komponen indikator dan tujuan pembelajaran. Indikator merupakan penanda pencapaian KD secara spesifik yang dapat dijadikan ukuran untuk mengetahui ketercapaian tujuan pembelajaran (Nadzir, 2013). Indikator dirumuskan dengan kata kerja operasional yang bisa diukur dan dibuat instrumen penilaiannya. Dalam penelitian ini indikator dikembangkan mahasiswa ke dalam tiga ranah yakni ranah kognitif, ranah sikap dan ranah psikomotorik. Hasil penelitian menunjukkan bahwa pada siklus I masih terdapat beberapa RPP yang belum bisa merumuskan indikator dan tujuan pembelajaran secara tepat. Hal ini terekam dalam fase presentasi dan penilaian dalam model PjBL. Meskipun model PjBL menuntut mahasiswa untuk menemukan konsep secara mandiri, namun dalam fase presentasi dan penilaian, kekeliruan ataupun kesalahan yang dilakukan pebelajar dapat diminimalisir dan diperbaiki. Untuk mengatasi hal tersebut, pada siklus II peneliti menyiapkan contoh RPP yang dilengkapi dengan cara perumusan indikator dan rumusan masalah yang benar. Sehingga dapat dijadikan rujukan bagi mahasiswa dalam mengembangkan aspek tersebut.

Penentuan rumusan indikator dan tujuan pembelajaran akan mempengaruhi keluasan konten materi. Untuk mengukur hal tersebut, mahasiswa tidak hanya ditugaskan untuk melengkapi komponen tersebut di dalam RPP, namun juga diminta untuk mbuat ringkasan materi pembelajaran. Pada aspek ini dilakukan dengan baik pada siklus I maupun siklus II. Sedangkan pada komponen strategi pembelajaran masih ditemukan kekurangan pada siklus I dimana strategi pembelajaran yang dipilih masih belum mengakomodir tujuan pembelajaran yang mencakup tiga ranah, yakni kognitif, afektif dan psikomotorik. Menurut (Ariesta, 2018) pemilihan strategi pembelajaran harus sesuai dengan karakteristik pembelajaran IPS yang dapat mengakomodasi pengetahuan dan pemahaman, sikap belajar IPS dan keterampilan IPS.

Strategi pembelajaran yang dipilih berpengaruh terhadap langkah-langkah pembelajaran yang terdiri atas kegiatan awal, kegiatan inti dan kegiatan penutup. Sehingga pada siklus I komponen ini juga masih belum mencapai hasil yang diinginkan. Hal yang sama juga berlaku dalam pemilihan media dan sumber belajar serta penilaian pada siklus I. Namun kondisi tersebut mengalami peningkatan pada siklus II setelah dosen memberikan bahan ajar yang memuat contoh RPP lengkap. Model PjBL memperluas dan memperkaya pengetahuan yang dimiliki oleh mahasiswa, karena PjBL akan membantu membangun konstruksi pengetahuan siswa berdasarkan struktur pengetahuan yang kokoh sehingga dapat membantu meningkatkan kemampuan analitik dalam memecahkan permasalahan. Hal ini terbukti dari peningkatan keterampilan mahasiswa dalam mengembangkan RPP dari siklus I ke siklus II. Rata-rata keterampilan tersebut meningkat dari $68 \%$ menjadi 85\%. Temuan ini juga serupa dengan temuan Rahayu \& Samsudin, (2019) yang menerapkan model PjBL pada mahasiswa PGSD Ikip Siliwangi yang terbukti dapat meningkatkan kompetensi menyusun perencanaan pembelajaran. Hasil penelitian ini menunjukkan bahwa model PjBL dapat diterapkan untuk meningkatkan proses perkuliahan desain pembelajaran IPS untuk sekolah dasar. Model PjBL terbukti lebih baik dibandingkan dengan model lain. Hal ini dibuktikan dalam penelitian Prabasari et al. (2021) dimana hasil belajar siswa yang diterapkan dengan model PjBL lebih tinggi dibandingkan dengan hasil belajar siswa yang diterapkan dengan model problem solving. Menurut Trianto, Project Based Learning adalah sebuah model inovatif, yang menekankan belajar kontekstual melalui kegiatan-kegiatan yang kompleks (Widodo \& Effendi, 2021). Dengan diterapkannya model PjBL pada perkuliahan desain pembelajaran IPS SD, mahasiswa PGSD Uniflor dilatih untuk dapat mengembangkan kreatifitasnya dalam menyusun perencanaan pembelajaran berbasis kearifan lokal NTT sehingga dihasilkan beberapa RPP yang memuat kebudayaan masyarakat setempat. Namun demikian, penelitian ini masih dibatasi dalam peningkatan kompetensi menyusun RPP 
978 Peningkatan Kompetensi Menyusun Rencana Pembelajaran Melalui Model Project Based Learning pada Mahasiswa PGSD - Manggu Ngguna Raji, Felix Welu

DOI : https://doi.org/10.31004/edukatif.v3i3.488

sehingga perlu dikembangkan penelitian lanjutan yang difokuskan pada indikator-indikator lain dalam proses perkuliahan desain pembelajaran.

\section{KESIMPULAN}

Berdasarkan hasil penelitian dapat disimpulkan bahwa penerapan model PjBL dapat meningkatkan kompetensi menyusun perencanaan pembelajaran IPS SD pada mahasiswa PGSD Universitas Flores. Setelah diterapkan model PjBL ini mahasiswa dapat mengembangkan kreatifitas menyusun RPP berbasis kebudayaan lokal NTT. Sehingga disarankan untuk digunakan model serupa dalam meningkatkan kemampuan merancang RPP bagi calon guru.

\section{UCAPAN TERIMA KASIH}

Terima kasih dihaturkan kepada program studi pendidikan guru sekolah dasar Universitas Flores yang telah mensponsori penelitian ini.

\section{DAFTAR PUSTAKA}

Ariesta, F. (2018). Karakteristik IPS di Sekolah Dasar. https://pgsd.binus.ac.id/2018/01/08/karakteristik-ipsdi-sekolah-dasar/

Fitri, H., Dasna, I. W., \& Suharjo, S. (2018). Pengaruh Model Project Based Learning (PjBL) Terhadap Kemampuan Berpikir Tingkat Tinggi Ditinjau dari Motivasi Berprestasi Siswa Kelas IV Sekolah Dasar. Briliant: Jurnal Riset Dan Konseptual, 3(2), 201. https://doi.org/10.28926/briliant.v3i2.187

Irianti, R. (2017). Improving Creative Thinking Skills by Implementing Project Based Learning on Human Organ System Material. 3(1), 42-45. https://doi.org/10.2991/seadric-17.2017.81

Istiqomah, J. Y. N., \& Indarini, E. (2021). Meta Analisis Efektivitas Model Problem Based Learning dan Problem Posing Terhadap Kemampuan Berpikir Kritis Siswa Sekolah Dasar Pada Pembelajaran Matematika. Jurnal Cendekia: Jurnal Pendidikan Matematika, 5(1), 670-681. https://doi.org/10.31004/cendekia.v5i1.553

Mulyadi, E. (2016). Penerapan Model Project Based Learning untuk Meningkatan Kinerja dan Prestasi Belajar Fisika Siswa SMK. Jurnal Pendidikan Teknologi Dan Kejuruan, 22(4), 385. https://doi.org/10.21831/jptk.v22i4.7836

Munawaroh, R., Subali, B., \& Sopyan, A. (2012). Penerapan Model Project Based Learning Dan Kooperatif Untuk Membangun Empat Pilar Pembelajaran Siswasmp. Unnes Physics Education Journal, 1(1). https://doi.org/10.15294/upej.v1i1.773

Nadzir, M. (2013). Perencanaan Pembelajaran Berbasis Karakter.

Nurjaman, A., Purwasih, R., \& Sari, I. P. (2018). Meningkatkan Kemampuan Mahasiswa Dalam Membuat RPP Melalui Penerapan Model Pembelajaran Project Based Learning. Jurnal Penelitian Matematika Dan Pendidikan Matematika, 2(2), 33-42. https://doi.org/10.15797/concom.2019..23.009

Prabasari, F., Putri, W., Koeswanti, H. D., Giarti, S., Kristen, U., \& Wacana, S. (2021). EDUKATIF : JURNAL ILMU PENDIDIKAN Perbedaan Model Problem Based Learning dan Project Based Learning Terhadap Hasil Belajar Siswa Sekolah Dasar Abstrak. 3(2), 496-504.

Prabawa, E. A. (2017). Analisis Kemampuan Pemecahan Masalah Ditinjau Dari Gaya Kognitif Siswa pada Model Project Based Learning Bernuansa Etnomatematika. Unnes Journal of Mathematics Education Research, 6(1), 120-129. 
979 Peningkatan Kompetensi Menyusun Rencana Pembelajaran Melalui Model Project Based Learning pada Mahasiswa PGSD - Manggu Ngguna Raji, Felix Welu

DOI : https://doi.org/10.31004/edukatif.v3i3.488

Rahayu, G. D. S., \& Samsudin, A. (2019). Penerapan Model Project Based Learning Dalam P2M STKIP Siliwangi. Jurnal Ilmiah UPT P2M STKIP Siliwangi, 6(2), 1-7.

Rahmah, N. (2018). Belajar Bermakna Ausubel. Al-Khwarizmi: Jurnal Pendidikan Matematika Dan Ilmu Pengetahuan Alam, 1(1), 43-48. https://doi.org/10.24256/jpmipa.v1i1.54

Rahmazatullaili, R., Zubainur, C. M., \& Munzir, S. (2017). Kemampuan berpikir kreatif dan pemecahan masalah siswa melalui penerapan model project based learning. Beta: Jurnal Tadris Matematika, 10(2), 166-183. https://doi.org/10.20414/betajtm.v10i2.104

Rais, M. (2007). MODEL PROJECT BASED-LEARNING SEBAGAI UPAYA MENINGKATKAN PRESTASI AKADEMIK MAHASISWA.

Setiana, D. S. (2018). Meningkatkan kemampuan menyusun RPP dengan pendekatan saintifik mahasiswa pendidikan matematika Universitas Sarjanawiyata Taman Siswa Yogyakarta. Prosiding Seminar Nasional MIPA $\quad 2018, \quad 120-131$. https://proceeding.unnes.ac.id/index.php/SNMIPA/article/view/215/171

Suranti, N. M. Y., Gunawan, G., \& Sahidu, H. (2017). Pengaruh Model Project Based Learning Berbantuan Media Virtual Terhadap Penguasaan Konsep Peserta didik pada Materi Alat-alat Optik. Jurnal Pendidikan Fisika Dan Teknologi, 2(2), 73. https://doi.org/10.29303/jpft.v2i2.292

Surya, A. P., Relmasira, S. C., \& Hardini, A. T. A. (2018). PENERAPAN MODEL PEMBELAJARAN PROJECT BASED LEARNING (PjBL) UNTUK MENINGKATKAN HASIL BELAJAR DAN KREATIFITAS SISWA KELAS III SD NEGERI SIDOREJO LOR 01 SALATIGA. Jurnal Pesona Dasar, 6(1), 41-54. https://doi.org/10.24815/pear.v6i1.10703

Widodo, S., \& Effendi, R. (2021). EDUKATIF : JURNAL ILMU PENDIDIKAN Penerapan Project Based Learning Berbasis Keterampilan Sosial Mata Pelajaran Kewarganegaraan di Sekolah Menengah Atas Abstrak. 3(2), 487-495. 